\title{
Teologiczne podstawy reguł sensu czynności konwencjonalnych i norm kompetencyjnych w prawie kanonicznym i ich konsekwencje dla decyzji prawodawczych
}

\section{Prawodawca kościelny: teolog i prawnik}

Prawo kanoniczne mimo swojej specyfiki jest prawdziwym prawem ${ }^{1}$. To stwierdzenie wypracowane i dowiedzione przez włoską szkołę prawa kanonicznego, jest powszechnie znane i akceptowane ${ }^{2}$.

Taki stan rzeczy implikuje określone konsekwencje dla prawodawcy kościelnego. Jedną z nich jest stawiany mu dezyderat, aby prawo przez niego uchwalane, było poprawne prawnie, to znaczy, aby powstawało w oparciu

\footnotetext{
I Tak w oparciu o „świecką włoską szkołę prawa kanonicznego” mówi: R. Sobański, Nauki podstawowe prawa kanonicznego, t. 1: Teoria prawa kościelnego, Warszawa 2001, s. 12-16; czy w oparciu o jurysprudencję anglosaską (L. Fuller, J. Raz): P. Kroczek, The Art of Legislation: Principles of Lawgiving in the Church, Kraków 2012, s. 38.

${ }_{2} \mathrm{Na}$ temat tego nurtu myśli kanonicznej zob. R. Sobański, Szkoły kanonistyczne, Warszawa 2009, s. 72-85.
} 
o osiągnięcia świeckiej nauki prawa ${ }^{3}$ Kanonistyka musi być gotowa do zapożyczeń ze świeckiego prawoznawstwa, oczywiście z uwzględnieniem własnej specyfiki ${ }^{4}$.

Jednak od prawodawcy kościelnego, ze względu na wspomnianą wyjątkowość prawa, które stanowi, wymaga się, aby czynności prawotwórcze, które podejmuje były zgodne z sensus Ecclesiae oraz missio Ecclesiae. Wymaga to od prawodawcy wzięcia pod uwagę w swojej pracy ustawodawczej teologicznych elementów zarówno jego prawotwórczych decyzji, jak i treści uregulowań, które stanowi ${ }^{5}$.

Tak więc nauka prawa musi w pracy prawodawcy kościelnego nie tylko współistnieć, ale i współdziałać z prawdami teologicznymi. Zaniedbanie któregoś ze wspominanych elementów może odbić się negatywnie na jakości prawa. Może to mieć poważne konsekwencje dla wspólnoty wiernych.

Niniejszy artykuł przedstawia powiązanie teologii i jurysprudencji w pracy prawodawcy kościelnego na przykładzie teologicznych podstaw reguł sensu czynności konwencjonalnych oraz norm kompetencyjnych zawartych w KPK z $1983^{6}$ oraz ukazuje ich konsekwencje dla decyzji prawodawczych. Artykuł ma na celu, poprzez dokonanie wspomnianej prezentacji, wskazanie prawodawcy kościelnemu obszaru, który powinien podlegać jego szczególnej, bo wymagającej znajomości prawoznawstwa i teologii, uwadze.

\section{Czynności konwencjonalne i normy kompetencyjne w nauce prawa}

W nauce prawa czynność konwencjonalną definiuje się jako celowe i świadome zachowanie podmiotu prawa (zarówno podmiotu prywatnego, jak

3 P. Kroczek, Zagadnienie interdyscyplinarności prawa kanonicznego, „Polonia Sacra”, 2010, t. 26, s. 175.

4 R. Sobański, Prawo kanoniczne a kultura prawna, „Prawo Kanoniczne”, R. 35, 1992, nr 1-2, s. 30 .

s. Kroczek, Prawodawca i jego sztuka, „Prawo Kanoniczne”, R. 50, 2007, nr 1-2, s. $179-180$.

6 Cytowane kanony odnoszą się do Codex Iuris Canonici auctoritate Ioannis Pauli PP. II promulgatus, 25 I 1983, „Acta Apostolicae Sedis”, R. 75, 1983, cz. 2, s. 1-301 [dalej: AAS]; tekst łacińsko-polski: Kodeks prawa kanonicznego. Przekład polski zatwierdzony przez Konferencję Episkopatu, Poznań 1984. 
i publicznego), któremu reguły, określane jako reguły sensu, przypisują jakieś znaczenie, czyli określają doniosłość tych zachowań w porządku normatywnym $^{7}$. Jest to definicja sensu stricto, która ogranicza czynności konwencjonalne do tych dokonywanych i skutecznych w porządku prawnym. Do zakresu przedmiotowego nazwy „czynność konwencjonalna”, w ujęciu wspomnianej definicji, należą więc tylko te czynności konwencjonalne, które mają określoną doniosłość wynikającą z norm prawnych. Poza optyką tego artykułu są czynności konwencjonalne ujęte sensu largo, czyli wykonywane w porządku kulturowym lub porządku zwyczajowym. Czynności te bowiem mają własne znaczenie na płaszczyznach innych niż prawna.

Aby czynność konwencjonalna była ważna, musi być dokonana przez podmiot posiadający odpowiednie kompetencje do jej dokonania, nadane przez normy kompetencyjne, oraz musi być sensowna według własnych reguł sensowności. Oczywiście w regułach sensowności może być także określony podmiot oraz warunki jego kompetencji do dokonania określonej czynności konwencjonalnej. Wspomniane reguły sensu mają postać norm prawnych ustanawianych przez prawodawcę w zasadzie w dowolny sposób. Wola prawodawcy ma moc konstytutywną dla istnienia reguł i ich normatywnych treści. W przypadku pozaprawnych czynności konwencjonalnych ich reguły sensu są ustalane przez inny podmiot niż prawodawca, często spontanicznie.

Każda czynność konwencjonalna (nie tylko ta o doniosłości prawnej) ma substrat materialny. Jest to nośnik treści i znaczeń tej czynności. Tym medium są czynności psychofizyczne lub ich wytwory, czyli słowa lub gesty, przez które czynności psychiczne się uzewnętrzniająa ${ }^{8}$ Jednakże sam ten element materialny czynności konwencjonalnej nie ma oczywiście jeszcze żadnej doniosłości w porządku normatywnym, jako przejaw tejże czynności konwencjonalnej. Nie należy jednak wykluczać, iż ten element materialny może mieć znaczenie prawne jako zachowanie, które nie ma charakteru czynności konwencjonalnej, lecz ma znaczenie prawne jako czyn.

A. Bator, Czynność konwencjonalna, [w:] A. Bator, W. Gromski, A. Kozak, S. Kaźmierczyk, Z. Pulka, Wprowadzenie do nauk prawnych. Leksykon tematyczny, red. A. Bator, Warszawa 2010, s. 89. L. Nowak, S. Wronkowska, M. Zieliński, Czynności konwencjonalne w prawie, „Studia Prawnicze”, 1972, z. 33, s. 73.

8 A. Bator, Czynność psychofizyczna, [w:] A. Bator, W. Gromski, A. Kozak, S. Kaźmierczyk, Z. Pulka, Wprowadzenie do nauk prawnych..., dz. cyt., s. 91. 
Ten brak doniosłości w porządku prawnym samego substratu materialnego, jako czynności konwencjonalnej, wynika z tego, że niezbędne są normatywne reguły znaczeniowe (reguły sensu), przypisujące elementowi materialnemu sens, który zwiąże ten element z czynnością konwencjonalną. Te reguły są ustanawiane przez prawodawcę lub też ukształtowane spontanicznie, a prawodawca nakazał ich stosowanie (zob. kan. 23)9.

Reguły te mogą mieć różne źródła. Przykładowo może być nimi wola prawodawcy, zwyczaj, kultura, a w przypadku prawa kanonicznego należy jeszcze dodać źródło teologiczne. To te źródła są teoretyczną podstawą dla ustanowienia przez prawodawcę normatywnych reguł sensu czynności konwencjonalnych ${ }^{10}$.

Jak już wspomniano, czynności konwencjonalne mogą być kwalifikowane jako ważne albo nieważne w zależności, czy są one dokonane przez podmiot posiadający odpowiednie kompetencje do ich dokonania oraz czy były dokonane zgodne z regułami sensu ${ }^{11}$. Nieważność czynności można uznać za specyficzną sankcję w przypadku naruszenia tych reguł ${ }^{12}$. Można jednakże powiedzieć, że działania niezgodne z regułami sensu nie są czynnościami konwencjonalnymi określonego rodzaju ${ }^{13}$. Skutki prawne czynności konwencjonalnej mogą polegać przykładowo na powstaniu obowiązku, uprawnienia, kompetencji prawnej.

Trzeba zaznaczyć, że nieważne czynności konwencjonalne prawodawca może różnie traktować. Może uważać je za bezwzględnie nieważne albo obalalne, to znaczy takie, które są ważne dopóki określony podmiot w określonej procedurze nie ustali ich nieważności z powodu określonych wad prawnych. W przypadku dokonania tych przepisanych czynności z pozytywnym skutkiem, czynność konwencjonalna obalalna może być nieważna od samego początku (ex tunc) albo od momentu ukończenia wspomnianej procedury (ex nunc).

9 Jest to problem analogiczny do źródła prawa zwyczajowego: wola społeczności (źródło materialne lub przyczyna bliższa) i jej zachowanie określone przesłankami czy akceptacja zwyczaju przez prawodawcę (źródło formalne lub przyczyna)? Historię formowania się doktryny referuje R. Sobański, Nauki podstawowe prawa kanonicznego, t. 1: Teoria prawa kościelnego, Warszawa 2001, s. 57-62.

Io S. Wronkowska, Podstawowe pojęcia prawa i prawoznawstwa, Poznań 2005, s. 178.

II M. Zieliński, Wyktadnia prawa. Zasady. Reguty. Wskazówki, Warszawa 2012, s. 26.

I2 A. Bator, Czynność konwencjonalna, dz. cyt., s. 90.

I3 S. Wronkowska, Podstawowe pojęcia..., dz. cyt., s. 178. 
Regułami sensu nie jest objęta kwestia, czy ktoś ma obowiązek dokonania określonej czynności konwencjonalnej, lecz wskazują one wyłącznie, jak należy się zachować, żeby osiagnać zamierzone cele. O regułach sensu mówi się, że czynności konwencjonalne stanowią hipotezę normy prawnej, z którą związana jest dyspozycja określająca, kto i jak, w razie dokonania czynności konwencjonalnej, powinien się zachować.

Z kolei norma kompetencyjna to norma udzielająca jakiemuś podmiotowi (osobie, czy też organowi) kompetencji, czyli upoważnienia do dokonania określonych czynności konwencjonalnych ${ }^{14}$. Nie można mówić o kompetencji do dokonania czynności konwencjonalnej doniosłej w prawie bez odwołania się do tej normy, która określając sposób dokonania czynności i jej reguły sensu, wyznaczałaby skutki prawne danej czynności w postaci zaktualizowania, wyznaczenia lub zmodyfikowania obowiązków prawnych jakichś podmiotów ${ }^{15}$.

Norma kompetencyjna kształtuje więc specyficzny stosunek prawny pomiędzy podmiotami w prawie, a mianowicie podmiotem kompetencji i podmiotem podległym kompetencji. Jeżeli pierwszy z nich dokona, wykonując swoją kompetencję w sposób ważny, określoną czynność konwencjonalną, to po stronie drugiego podmiotu powstanie określony obowiązek prawny ${ }^{16}$. Można więc powiedzieć, że norma kompetencyjna to norma nakładająca obowiązek lub uchylająca go będąca konsekwencją ważnego wykonania przez dany podmiot posiadanej kompetencji prawnej.

Adresatem tej normy jest zwykle podmiot podległy kompetencji. Niekiedy adresatem normy kompetencyjnej może być również podmiot, który uzyskuje w jej wyniku kompetencję, czyli przykładowo zobowiązuje go ona do reagowania w określony w sposób na swoją czynność ${ }^{17}$. Trzeba zwrócić uwagę na to, że norma kompetencyjna określa nie tylko określa stosunek prawny istniejący pomiędzy adresatem obowiązku i jego podmiotem nadrzędnym, lecz również wskazuje na podmiot kompetencji ${ }^{18}$. Podmiot ten

${ }^{14}$ Nie chodzi tu więc o umiejętność czy znajomość reguł przyjmowaną w określonej dziedzinie; zob. Z. Ziembiński, $O$ zawiłościach związanych z pojmowaniem kompetencji, „Państwo i Prawo”, R. 46, 1991, z. 4, s. 14.

is Tamże, s. 16-17.

i6 S. Wronkowska, Podstawowe pojęcia prawa..., dz. cyt., s. 19-20.

${ }_{17}$ M. Zieliński, Wyktadnia prawa..., dz. cyt., s. 27, przyp. 32.

i8 A. Bator, Norma kompetencyjna, [w:] A. Bator, W. Gromski, A. Kozak, S. Kaźmierczyk, Z. Pulka, Wprowadzenie do nauk prawnych..., dz. cyt., s. 121-123. 
może mieć przyznane kompetencje generalne do całego zespołu czynności konwencjonalnych albo do poszczególnej czynności ${ }^{19}$.

Zazwyczaj nie istnieje prawny obowiązek skorzystania z normy kompetencyjnej, czyli zaktualizowania swojej kompetencji. Niekiedy jednak kompetencja łączy się z takim obowiązkiem. Przykładowo obowiązek ten istnieje na gruncie prawa administracyjnego ${ }^{20}$. Należy także zauważyć, że w systemie społecznym mogą istnieć normy postępowania zakazujące podmiotowi kompetentnemu skorzystania z kompetencji. Różne mogą być wówczas konsekwencje prawne skorzystania z tej kompetencji pomimo zakazu. Może być nimi nieważność czynności konwencjonalnej, możliwość unieważnienia takiej czynności albo ważność czynności, lecz połączona z restrykcjami wobec podmiotu dokonującego tej czynności ${ }^{21}$.

Norma kompetencyjna wyrażana jest zwykle w tekście prawnym poprzez wyrażenia takie jak: „ma prawo” (np. art. $812 \$ 1$ k.c. ${ }^{22}$ ), „przysługuje mu prawo” (np. art. $991 \$ 1$ k.c.), „może” (np. art. $18 \$ 1$ k.c.) ${ }^{23}$. W oryginalnym tekście łacińskim KPK z 1983 zwroty wyrażające kompetencje oparte są na czasownikach takich jak „possum” (np. kan. $1565 \$ 1$, kan. 1672) czy też „spectare” (np. kan. 470, kan. 584). Wiele razy kompetencja wyrażona jest poprzez zwroty takie jak ,ius est” (kan. 213, kan. 214), „ius habet” (kan. 1146, kan. 1738), „ius gaudet” (kan. $221 \$ 1$ ). Niekiedy także rzeczowniki „potestas” lub „facultas” w połączeniu z czasownikami, takimi jak przykładowo „habet” czy „gaudet” (np. kan. 667 \$ 4, kan. 691 \$2), wyrażają przepis nadający kompetencję ${ }^{24}$.

19 M. Zieliński, Wykładnia prawa..., dz. cyt., s. 28.

20 Zob. M. Zieliński, Dwa nurty pojmowania „kompetencji”, [w:] Gospodarka, administracja, samorzad, red. H. Olszewski, B. Popowska, Poznań 1997, s. 581-608.

2I Szerzej zob. M. Zieliński, Wyktadnia prawa..., dz. cyt., s. 29-30.

22 Ustawa z 23 kwietnia 1964 r. - Kodeks cywilny (Dz.U. Nr 16, poz. 93, z późn. zm.).

23 M. Zieliński, Wyktadnia prawa..., dz. cyt., s. 135-136.

${ }_{24}$ Szerzej o tym zob. P. Kroczek, The Art of Legislation: the Principles of Lawgiving in the Church, Kraków 2011, s. 146. 


\section{Niektóre czynności konwencjonalne w Kodeksie prawa kanonicznego z 1983 roku}

W Kodeksie prawa kanonicznego z 1983 roku można odnaleźć liczne przepisy regulujące czynności konwencjonalne. Na potrzeby niniejszego artykułu niektóre z nich zostały uporządkowane i przedstawione w określonym porządku, czyli począwszy od tych reguł sensu, których teologiczna implikacja jest największa, do tych reguł sensu, które, jak się wydaje, takiej implikacji nie podlegają.

\subsection{Przyjęcie święceń}

Nie wnikając w skutki święceń w postaci łaski sakramentu, którą otrzymuje przyjmujący święcenia, należy stwierdzić, że obrzęd przyjęcia święceń duchownych jest czynnością konwencjonalną, której prawnym skutkiem jest włączenie osoby do grupy duchownych (por. kan. $207 \$ 1$ ).

Prawodawca w kan. 1024 zawarł podstawową regułę, iż „święcenia ważnie przyjmuje tylko mężczyzna ochrzczony”. Jest wiele racji teologicznych przemawiających za tą doktryną, m.in., przykład, jaki pozostawił Jezus Chrystus, wybierając dwunastu apostołów, niezmienna i powszechna Tradycja Kościoła, wreszcie żywe Magisterium Kościoła, konsekwentnie głoszące, że wykluczenie kobiet z kapłaństwa jest zgodne z zamysłem Boga. Te i inne racje teologiczne zostały wielokrotnie i jasno wyłożone przez Kościół ${ }^{25}$. Nauka ta w zakresie „ordinatio sacerdotalis” została określona jako „orzeczenie ostateczne"26.

${ }^{25}$ Dokumenty kościelne wykładające naukę katolicką oraz regulujące dyscyplinę w tym zakresie zob. Sacra Congregatio pro Doctrina Fidei, Dectaratio Inter insigniores circa quaestionem admissionis mulierum ad sacerdotium ministeriale, 15 X 1976, AAS, R. 69, 1977, s. 98-116; Ioannes Paulus II, Litterae Apostolicae Ordinatio sacerdotalis de Sacerdotali ordinatione viris tantum reservanda, AAS, R. 86, 1994, s. 545-548 [dalej: Ordinatio sacerdotalis].

${ }_{26}$ Ordinatio sacerdotalis, nr 4: „Ut igitur omne dubium auferatur circa rem magni momenti, quae ad ipsam Ecclesiae divinam constitutionem pertinet, virtute ministerii Nostri confirmandi fratres (cf. Lc 22, 32), declaramus Ecclesiam facultatem nullatenus habere ordinationem sacerdotalem mulieribus conferendi, hancque sententiam ab omnibus Ecclesiae fidelibus esse definitive tenendam" oraz Congregatio pro Doctrina Fidei, Respon- 
Tak więc błędne jest twierdzenie, że decyzja Kościoła, by nie dopuszczać kobiet do święceń kapłańskich ma jedynie charakter dyscyplinarny ${ }^{27}$. Wszystko to powoduje, że najwyższy prawodawca kościelny nie może dać posłuchu postulatom i wnioskom, aby zmienić reguły sensu i uczynić możliwym przyjęcie święceń przez kobiety ${ }^{28}$. Jego możliwości działania prawodawczego są bowiem mocno ograniczone.

\subsection{Zawarcie małżeństwa}

Także zawarcie małżeństwa jest czynnością konwencjonalną bardzo mocno uwarunkowaną teologicznie. Chodzi tu o heteroseksualny charakter związku małżeńskiego, który wynika z prawa Bożego naturalnego (zob. Rdz 1, 2728; Rdz 2, 18; $\operatorname{Rdz} 2,23-24)^{29}$. Na tym prawno-naturalnym fundamencie prawodawca kościelny ustanowił regułę głoszącą, iż sensowne, a w rezultacie ważne i skuteczne jest małżeństwo wyłącznie zawarte pomiędzy mężczyzną i kobietą (kan. $1055 \$ 1$, por. kan. $1057 \$ 2)^{30}$.

Wprawdzie prawodawca kościelny może kreować rzeczywistość poprzez uchwalane przez siebie regulacje (np. tworząc lub zmieniając instytucje prawne), to jednak powinien liczyć się z tym, że nie ma on takiej swobody legislacyjnego działania, jak ustawodawca niekościelny.

sum ad dubium circa doctrinam in Epist. Ap. Ordinatio Sacerdotalis traditam, AAS, R. 87, 1995, s. 1114.

27 Ordinatio sacerdotalis, $\mathrm{nr} 4$.

28 Literatura jest bardzo bogata, wystarczy wymienić: The Ordination of women, pro and con, red. H. M. Pollock, N. S. Montgomery, New York 1975; Women Priests: a Catholic Commentary on the Vatican Declaration, red. L. and A. Swidler, New York 1977; Women in the Church, red. M. Kolbenschlag, Washington 1987; The Welcome Table: Setting a Place for Ordained Women, red. P. A. Habada, R. Frost Brillhart, Langley Park 1995; S. M. St. Pierre, The Struggle to Serve: the Ordination of Women in the Roman Catholic Church, Jefferson 2011.

29 W. Góralski, Prawo Boże jako źródto kościelnego prawa matżeńskiego w Kodeksie Prawa Kanonicznego Jana Pawła II, [w:] Studia nad matżeństwem i rodzina, Warszawa 2007, s. 17.

30 Szerzej ten problem omawia: P. Kroczek, Prawo świeckie jako bariera komunikacyjna dla niektórych treści nauczania Kościoła o matżenstwie i rodzinie, [w:] Rodzina podmiotem wychowania i kreatorem komunikacji społecznej, red. N. Pikuła, Kraków 2010, s. 331-344. 


\subsection{Udzielenie błogosławieństwa}

Błogosławieństwo to wstawiennicza modlitwa błagalna człowieka lub Kościoła o dobro od Pana Boga, często w określonej formie liturgicznej jako sakramentalium ${ }^{31}$. Prowadzi ono wiernych do uwielbienia Boga i przygotowuje do przyjęcia sakramentów, a także uświęca różne okoliczności ludzkiego życia. Przynosi więc skutki, zwłaszcza duchowe (kan. 1166).

Przede wszystkim z tej racji, że liturgia Kościoła nie jest sprawą prywatną, musi być sprawowana „w imieniu Kościoła przez osoby prawnie do tego wyznaczone i z zastosowaniem aktów zatwierdzonych przez władzę kościelną" (kan. $834 \$ 2$ ). Tak więc błogosławieństwa muszą być dokonane według przepisów ksiąg liturgicznych (zob. kan. 2015, kan. 1229, kan. $1237 \$ 1)^{32}$.

Czynność psychofizyczna związana z błogosławieństwem jest określona jako „układ podstawowy” błogosławieństwa. Składa się ona z dwóch części, z których „pierwszą stanowi głoszenie słowa Bożego, drugą zaś uwielbienie Bożej dobroci i modlitwa o pomoc z nieba"33. Modlitwom często towarzyszą znaki, które - jak głosi Sobór Watykański II - zmierzają do tego, aby przypomnieć zbawcze działanie Boga, ukazać związek pomiędzy sakramentaliami a sakramentami, pobudzić uwagę wiernych do uczestnictwa i wzmocnić $\mathrm{w}$ nich wiarę (SC ${ }^{34} \mathrm{nr}$ 59-60). Jako przykładowe znaki wymienia się gesty rękami dokonywane przez szafarza błogosławieństwa: rozłożenie, podniesienie, złożenie, nałożenie rąk, znak krzyża. Do znaków należą także okadzenie i pokropienie wodą święconą ${ }^{35}$. Szczegółowe czynności szafarza

${ }^{3} \quad$ H. Schmitz, Benediction, [w:] Lexicon de Kirchenrechts, red. S. Haering, H. Schmitz, Freiburg-Basel-Wien 2004, kol. 47.

32 Odpowiedzialność za te czynności spoczywa m.in. na biskupie (kan. $835 \$ 1$ ), ordynariuszu miejsca (kan. 562), wikariuszu rejonowym (dziekanie) (kan. $555 \$ 1 \mathrm{nr} 3$ ), rektorze kościoła (kan. 562).

33 Wprowadzenie teologiczne i pastoralne, [w:] Obrzędy błogostawieństw dostosowane do zwyczajów diecezji polskich, t. 1-2, Katowice 1994, nr 20.

34 Sacrosanctum Concilium Oecumenicum Vaticanum II, Constitutio Sacrosanctum Concilium de Sacra Liturgia, 4 XII 1963, AAS, R. 56, 1964, s. 97-138; tekst łacińsko-polski: Sobór Watykański II, Konstytucja Sacrosanctum Concilium o liturgii świętej, [w:] Sobór Watykański II, Konstytucje, dekrety, deklaracje, Poznań 1986, s. 25-99.

35 Wprowadzenie teologiczne i pastoralne, dz. cyt., nr 26. 
przy wykonywaniu błogosławieństwa zależą od specyfiki błogosławieństwa i określone są w księgach liturgicznych ${ }^{36}$.

Kodeks prawa kanonicznego i regulacje dotyczące liturgii rozróżniają błogosławieństwa. To rozróżnienie dotyczy przedmiotu błogosławieństwa. Przykładowo przez błogosławieństwo miejsce staje się miejscem świętym (locis sacris) (zob. kan. 1205-1213), a rzecz rzeczą świętą (res sacrae) (zob. kan. 1235-1239).

Różne też są podmioty kompetentne do dokonania błogosławieństwa, gdyż „posługa błogosławieństwa łączy się ze szczególną formą sprawowania kapłaństwa Chrystusa zgodnie z miejscem i urzędem właściwym każdemu członkowi ludu Bożego"37 (zob. kan. $204 \$ 1$ ).

Generalny przepis ustanowiono w kan. 1168 - „szafarzem sakramentaliów jest duchowny wyposażony w odpowiednią władzę" (zob. kan. $266 \$ 1$ ). Z kolei w kan. $1169 \$ 2$ rozporządzono, że błogosławieństw, z wyjątkiem tych, które są zastrzeżone Papieżowi lub biskupom, może dokonywać każdy prezbiter. Natomiast diakon może dokonywać tylko tych błogosławieństw, na które mu prawo wyraźnie zezwala (kan. 1169 \$3).

Ciekawa jest sprawa przechodniej precedencji upoważnienia do udzielania błogosławieństwa. Otóż „biskupowi przysługuje prawo przewodniczenia zwłaszcza tym błogosławieństwom, które odnoszą się do całej wspólnoty diecezjalnej i są sprawowane szczególnie uroczyście przy udziale wielu wiernych" ${ }^{38}$. Natomiast prezbiterowi przysługuje prawo przewodniczenia błogosławieństwom, zwłaszcza sprawowanym we wspólnocie, do posługiwania której są przeznaczeni, czyli np. parafii. „Mogą oni sprawować wszystkie błogosławieństwa znajdujące się w tym zbiorze, chyba, że obecny jest biskup, który mógłby tym błogosławieństwom przewodniczyć"39. Diakon, jak to wynika z prawa powszechnego, także może dokonywać błogosławieństw, lecz ilekroć jest obecny kapłan, „stosowniej będzie, jeśli on przejmie obowiązek przewodniczenia” ${ }^{40}$.

${ }_{36} \mathrm{~Np}$. Obrzędy błogostawieństw dostosowane do zwyczajów diecezji polskich, t. 1-2, Katowice 1994.

37 Wprowadzenie teologiczne i pastoralne, dz. cyt., nr 28.

38 Tamże, nr 18a.

39 Tamże, nr 18b.

40 Tamże, nr 18c. 
Trzeba dodać, że niektórych sakramentaliów mogą, według uznania ordynariusza miejsca, udzielać także świeccy, posiadający odpowiednie przymioty (kan. 1168), np. akolici, lektorzy, którzy wykonują w Kościele własne posługi na podstawie specjalnego upoważnienia, oraz inni wierni świeccy, mężczyźni i kobiety, na mocy wspólnego kapłaństwa, które otrzymują w sakramencie chrztu i bierzmowania ${ }^{41}$. Jednak stanowczo trzeba podkreślić to, że gdy jest „obecny kapłan lub diakon, jemu przysługuje prawo przewodniczenia obrzędowi”"42.

Przykładowo, zgodnie z Ogólnym wprowadzeniem do liturgii godzin $n^{43}$ : „W razie nieobecności kapłana lub diakona przewodniczący oficjum jest tylko pierwszym spośród równych sobie; nie zasiada w prezbiterium, nie pozdrawia i nie błogosławi wiernych" (nr 258).

Specyficzną formą błogosławieństwa jest błogosławieństwo eucharystyczne. Zgodnie z kan. 943 kompetentny do udzielenia błogosławieństwa jest kapłan lub diakon. Akolita, szafarz nadzwyczajny Komunii świętej lub ktoś inny wyznaczony przez ordynariusza miejsca nie może tego dokonać, choć jest szafarzem wystawienia Najświętszego Sakramentu.

U podstaw przyznania określonej kompetencji do błogosławienia oraz przechodniości tego upoważnienia leżą racje natury teologicznej. Najważniejszą jest podział wiernych z ustanowienia Bożego na świętych szafarzy, których w prawie nazywa się też duchownymi, oraz pozostałych wiernych, których nazywa się świeckimi (kan. $207 \$ 1$ ).

Nawet, gdyby prawodawca przyznał kompetencje zarezerwowane osobie duchownej z racji teologicznych osobie świeckiej, dokonanie przez nią czynności byłoby tylko zewnętrznie poprawne, lecz niezgodne z racjami teologicznymi. Co więcej, gdyby nie zastosowano się do reguł precedencji, obraz hierarchicznego kształtu wspólnoty kościelnej byłby zafałszowany.

4I Tamże, nr $18 \mathrm{~d}$.

42 Tamże; zagadnienie współpracy wiernych świeckich z duchowieństwem było przedmiotem regulacji w postaci instrukcji: Congregatio pro Clericis et Aliae, Instructio Ecclesiae de mysterio de quibusdam quaestionibus circa fidelium laicorum cooperationem sacerdotum ministerium spectantem, AAS, R. 89, 1997, s. 852-877; tekst polski: Instrukcja o niektórych kwestiach dotyczących współpracy wiernych świeckich w ministerialnej posłudze kapłanów, „L'Osservatore Romano” (wyd. pol.), R. 19, 1998, nr 12, s. 30-40.

43 Ogólne wprowadzenie do liturgii godzin, Pallottinum 1992. 


\subsection{Udzielenie dyspensy}

Zgodnie z prawem powszechnym dyspensa to czynność konwencjonalna polegająca na rozluźnieniu prawa czysto kościelnego w poszczególnym wypadku (kan. 85). Prawo zasadniczo nie określa sposobu dokonania dyspensy. Ze względu na znaczenie prawa, od którego się dyspensuje, powinna być ona dokonana słownie lub na piśmie.

Dyspensa może zostać udzielona przez tych, którzy posiadają władzę wykonawczą w granicach ich uprawnień, a także przez tych, którym wyraźnie lub pośrednio przysługuje władza dyspensowania, bądź mocą samego prawa, bądź mocą zgodnej z prawem delegacji (kan. 85). Podmiot kompetentny do dokonania tej czynności jest więc ściśle określony przepisem ogólnym, przepisami szczegółowymi oraz normami wynikającymi z prawnej delegacji (por. kan. $132 \$ 1$, kan. 137, kan. 138).

Wprawdzie w kodeksie, w kan. 129 stanowi się, że tylko ci, którzy otrzymali święcenia, są zdolni ( habiles) do sprawowania władzy rządzenia, w której skład wchodzi władza wykonawcza (kan. $135 \$ 1$ ), lecz w $\$ 2$ cytowanego kanonu prawodawca, kierowany teologicznymi, które doszły do głosu podczas i po Soborze Watykańskim II racjami ${ }^{44}$, zezwolił, aby wykonywaniu tej władzy mogli współdziałać wierni świeccy. Oni bowiem także są „zdolni” ( habiles), zgodnie kan. $228 \$ 1$, otrzymać od świętych pasterzy te urzędy kościelne i posługi, które zgodnie z przepisami prawa wolno im piastować. Oznacza to, że wierni świeccy mogą uczestniczyć w sprawowaniu władzy w Kościele w zakresie władzy wykonawczej, w której ramach mieści się udzielanie dyspens.

Reguły sensu tej czynności konwencjonalnej ograniczają możliwość udzielenia dyspensy na prawa czysto kościelne (z wyjątkiem dyspensy od małżeństwa zawartego, lecz niedopełnionego oraz rozwiązania małżeństwa na korzyść wiary) (kan. $1143 \$ 1$ ). Prawo Boże jest więc prawem, od którego, z racji teologicznych, nie można dyspensować. Wynika to z tego, iż najwyższym prawodawcą jest Bóg ${ }^{45}$.

44 J. P. Beal, The Exercise of the Power of Governance by Lay People: State of the Question, "The Jurist”, R. 55, 1995, s. 1-92 i J. M. Huels, Power of Governance and Its Exercise by Lay Persons: a Juridical Approach, „Studia Canonica”, R. 35, 2001, s. 59-96.

45 Zob. inne wyłączenia spod przedmiotu dyspensowania przedstawione w kan. 86 i 87. Ich wyłączenie ma jednak charakter pozytywistyczno-prawny, a nie teologiczny. 
Teologiczne podstawy władzy dyspensowania leżą zarówno w określeniu podmiotów władzy kościelnej, jak i zakresie przedmiotowym prawa, któremu przez dyspensę „zadaje się ranę”, bowiem „dispensatio est vulnus [...] quia quasi vulnerat ius commune" 46 .

Jak widać na przykładzie kompetencji do udzielania dyspens od przeszkód małżeńskich, dyscyplina kościelna w tym zakresie ulegała na przestrzeni ostatnich 50 lat rozluźnieniu w ten sposób, że coraz więcej podmiotów w coraz szerszym zakresie takie kompetencje otrzymuje ${ }^{47}$. Oczywiście, trzeba zaznaczyć, że są przeszkody, np. niemocy płciowej (kan. $1084 \$ 1$ ) czy pokrewieństwa w pierwszym stopniu linii prostej (kan. $1091 \$ 1$ ), od których, $\mathrm{z}$ racji teologicznych, tj. prawa naturalnego Bożego, nie można i nie będzie można dyspensować. Prawodawca więc przy ustalaniu reguł sensu dyspensy musi liczyć się z pewnymi ramami, dla swoich prawodawczych decyzji, ustalonymi przez prawo wyższego stopnia.

\subsection{Udzielenie rozgrzeszenia}

Zgodnie z kan. 965 „szafarzem sakramentu pokuty jest tylko kapłan”. Kanon $966 \$ 1$ określa warunki niezbędne do ważnego odpuszczenia grzechów. Prawo wymaga, aby szafarz oprócz władzy święceń w stopniu prezbiteratu lub episkopatu posiadał upoważnienie do jej wykonywania w odniesieniu do wiernych, którym udziela rozgrzeszenia. Takie upoważnienie może kapłan otrzymać albo na mocy samego prawa, albo udzielenia dokonanego przez kompetentną władzę (kan. $966 \$ 2)$.

Czynność konwencjonalna polegająca, w normalnych warunkach ${ }^{48}$, na wysłuchaniu grzechów penitenta i wypowiedzeniu formuły rozgrzeszenia, gdy jest dokonana przez osobę niekompetentną, to znaczy osobę niemającą święceń kapłańskich lub kapłana bez upoważnienia, jest nieważna, a nawet powoduje negatywne skutki dla dokonującego takiej czynności. Kapłan, gdy usiłuje udzielić rozgrzeszenia i jest świadom, że nie ma upoważnienia

${ }^{46}$ L. de Miranda, Manuale praelatorum regularium, t. 2, Romae 1612, q. 2, art. IV.

47 Sprawę tę szczegółowo referuje np. T. Pawluk, Prawo kanoniczne wedtug Kodeksu Jana Pawta II, t. 3, Prawo matżenskie, Olsztyn 1996, s. 118-120.

${ }_{48}$ To jest przykładowo poza sytuacją niebezpieczeństwa śmierci (periculum mortis), zob. kan. 976 i 977. 
do tego, i jest ciężko poczytalny na skutek winy umyślnej lub nieumyślnej, popełnia przestępstwo i popada w karę suspensy latae sententiae; natomiast inna osoba zaciąga karę interdyktu (kan. 1378 \$ $2 \mathrm{nr} 2$ ).

\subsection{Przebaczenie małżonkowi winnemu zdrady}

Przebaczenie można zdefiniować jako akt uczuciowy dokonany w dowolnej formie, polegający na puszczeniu w niepamięć doznanej krzywdy i odczuwanej urazy. W prawie polskim przebaczenie nie jest utożsamiane z oświadczeniem woli, bowiem do dokonania przebaczenia nie wymaga się zdolności do czynności prawnych. Ustawodawca polski wymaga jednak od dokonującego przebaczenia „odpowiedniego rozeznania” (zob. art. 899 $\$ 1$, art. 930 art. $\$ 2$, art. $1010 \$ 2$ k.c.), czyli „woli puszczenia w niepamięć doznanej krzywdy" ${ }^{49}$.

Zagadnienie charakteru prawnego przebaczenia jest uznawane za wysoce kontrowersyjne $e^{50}$. Jednakże prawo polskie niekiedy przypisuje temu zachowaniu określone znaczenie prawne. Przykładem regulacji prawnej uwzględniającej przebaczenie jest art. 930 art. $\$ 1$ k.c., w którym stanowi się, że przebaczenie dokonane przez spadkodawcę wyklucza uznanie spadkobiorcy za niegodnego (zob. art. $899 \$ 1$ i art. 1010 k.c.). Przebaczenie wywiera więc w określonych okolicznościach skutki prawne.

Jednakże z racji teologicznych przebaczenie musi być uznane w prawie kanonicznym za czyn głębszy niż tylko odruch ludzki. Przez przebaczenie bowiem wierni wypełniają polecenie z Modlitwy Pańskiej (Mt 6, 9-13) i tym samym naśladują Jezusa Chrystusa. Zwarzywszy, że praktyka wiary ma swoje odzwierciedlenie w normach kanonicznych, wydaje się, że na polu prawa kościelnego można uznać przebaczenie za specyficzną czynność konwencjonalną.

Przebaczenie, którego źródło leży w ogólnoludzkich zachowaniach oraz podyktowane jest racjami religijnymi, znalazło w kan. $1152 \$ 1$ swoje znaczenie normatywne. Prawodawca wzywa w tym kanonie, aby małżonek niewinny, w przypadku zdrady, chrześcijańską miłością i zatroskany o dobro rodziny, nie odmawiał stronie cudzołożnej przebaczenia oraz nie zrywał z nią życia małżeńskiego. Ma on jednak prawo przerwać pożycie małżeńskie,

\footnotetext{
49 E. Skowrońska-Bocian, Prawo spadkowe, Warszawa 2012, s. 49.

so Tamże, s. 48.
} 
chyba że zgodził się na cudzołóstwo albo stał się jego przyczyną lub sam także popełnił cudzołóstwo. Małżonek nie ma także prawa do zerwania życia małżeńskiego, gdy darował winę małżonkowi cudzołożnemu. Prawodawca powszechny określa dwa możliwe sposoby przebaczenia. Przebaczenie to może się odbyć wyraźnie lub milcząco (expresse aut tacite) (kan. $1151 \$ 1$ ).

W przypadku wyraźnego przebaczenia współmałżonek niewinny po prostu dopuszcza z powrotem drugą stronę do życia małżeńskiego. W takim wypadku zrzeka się prawa do separacji (kan. 1155).

W tym drugim przypadku, czyli przebaczenia milczącego, przebaczenie ma miejsce, jeżeli strona niewinna, wiedząc o zdradzie małżeńskiej, dobrowolnie i z miłością małżeńską współżyje z tą stroną, która zawiniła. Domniemywa się, że nastąpiło darowanie winy, gdy małżonek niewinny mieszkał wspólnie z małżonkiem winnym przez sześć miesięcy od powzięcia wiadomości o złamaniu przez małżonka winnego przyrzeczenia wierności małżeńskiej i nie odwołał się w tym czasie ani do władzy kościelnej, ani do władzy świeckiej, w celu wyciągnięcia konsekwencji prawnych wobec małżonka winnego tego występku (kan. $1152 \$ 2)$. Na gruncie prawa polskiego mogłoby to być np. złożenie wniosku o rozwód czy separację, które w tym przypadku mogłoby być orzeczone $\mathrm{z}$ winy winnego małżonka (art. $56 \mathrm{i}$ art. $61^{1}$ w związu z art. 23 k.r.o. ${ }^{51}$ ). Natomiast na forum kanonicznym możliwym rozwiązaniem byłaby przykładowo separacja wieczysta ${ }^{52}$.

\subsection{Wydanie wyroku}

Sędzią dla swojej diecezji jest biskup diecezjalny. Tę funkcję może wykonywać osobiście albo przez sędziów (kan. $1419 \$ 1$, kan. $391 \$ 2)$. W praktyce w Kościele wyroki wydają pojedynczy sędziowie lub kolegia sędziowskie.

W Kodeksie prawa kanonicznego z 1917 roku $^{53} \mathrm{w}$ kan. 1574 przyznawano władzę sądzenia wyłącznie prezbiterom działającym z na mocy delegacji udzielonej przez biskupa. Po Soborze Watykańskim II zaczęto dyskutować

\footnotetext{
sr Ustawa z 25 lutego 1964 r. - Kodeks rodzinny i opiekuńczy (Dz.U. Nr 9, poz. 59, z późn. zm.)

s2 T. Pawluk, Prawo kanoniczne..., dz. cyt., s. 226.

53 Codex Iuris Canonici. Pii X Pontificis Maximi iussu digestus, Benedicti Papae XV auctoritate promulgatus, AAS, R. 9, 1917, cz. 2, s. 11-456.
} 
teologiczne podstawy przyznania wiernym świeckim możliwości udziału we władzy w Kościele, także w zakresie władzy sądzenia ${ }^{54}$.

W obowiązującym porządku prawnym sędzią obdarzonym specjalnym urzędem wikariusza sądowego lub zastępcy wikariusza sądowego może być tylko kapłan (sacerdos). Innymi sędziami mogą być co do zasady wyłącznie duchowni (clerici). W wyjątkowych okolicznościach, czyli w razie sytuacji konieczności stworzenia kolegium sędziowskiego (zob. kan. $1425 \$ 1$ i \$2), Konferencja Episkopatu może zezwolić, by sędziami mogli być ustanowieni także świeccy, lecz wyłącznie w przypadku, gdyby wierny świecki (oczywiście zarówno kobieta, jak i mężczyzna) był niezbędny do stworzenia kolegium sędziowskiego (kan. $1421 \$ 2$ ).

Czynności prowadzące do wydania wyroku, czyli dyskusja sprawy (kan. 1609), jak i sam wyrok są szczegółowo uregulowane (kan. 1611-1612). Jednakże czynności te, jeśli podejmuje je osoba nieupoważniona do tego z mocy prawa, są nieważne. Na tym przykładzie widać, że prawodawca musi liczyć się ze zmianami w spojrzeniu teologicznym, mają one bowiem przełożenie na reguły, które ustala przy określaniu niektórych czynności konwencjonalnych oraz norm kompetencyjnych.

\subsection{Bycie świadkiem kwalifikowanym małżeństwa}

Wprawdzie zgodnie z prawem kanonicznym o zawarciu małżeństwa decyduje wola nupturientów (consensus facit matrimionium ${ }^{55}$ ), jednakże musi być ona wyrażona w określonej prawem formie (kan. $1057 \$$ kan. 1108). Kanoniczna forma małżeństwa składa się z dwóch zasadniczych elementów. Pierwszy to aktywna obecność świadka kwalifikowanego, czyli ordynariusza miejsca, proboszcza lub prezbitera, ewentualnie diakona delegowanego przez nich (kan. $1108 \$ 1$ ) lub w wyjątkowych okolicznościach i po spełnieniu określonych prawem warunków - osoby świeckiej (1112\$1). Drugim jest

s4 J. P. Frattin, Lay Judges in Ecclesiastical Tribunals, "The Jurist”, R. 28, 1968, s. 177184; P. Beal, The Exercise of the Power of Governance by Lay People: State of the Question, „The Jurist”, R. 55, 1995, s. 1-92; J. M. Huels, Power of Governance and Its Exercise by Lay Persons: a Juridical Approach, „Studia Canonica”, R. 35, 2001, s. 59-96.

ss Iustiniani digesta, [w:] Corpus Iuris Civilis, editio stereotypa quinta, red. Th. Momsen, t. 1, Berlolini 1889, s. 1-873, tu: 50.17.30. 
obecność dwóch świadków zwykłych (kan. $1108 \$ 1$ ). W przypadku wady formy, z tej racji, że małżeństwo cieszy się przychylnością prawa, należy uważać je za ważne, dopóki nie udowodni się czegoś przeciwnego (kan. 1060).

Nie ma przeszkód, aby prawodawca kościelny uznał małżeństwa zawarte przed innymi świadkami, którzy wprawdzie nie są uznani za urzędowych przez regulacje prawa kanonicznego, ale pełnią analogiczną funkcję, a nawet wykonują analogiczne czynności ${ }^{56} \mathrm{~W}$ innych systemach prawnych, to znaczy np. są kierownikami USC, konsulami lub osobami upoważnionymi do pełnienia tej funkcji (art. $1 \$ 1 \mathrm{i} \$ 4$ k.r.o.) albo nawet bez nich, jak to byłoby w przypadku clandestina coniugia (clandestina matrimonia). Nie racje teologiczne, lecz jedynie duszpastersko-praktyczne dyktują prawodawcy utrzymanie obecnego rygoru prawnego ${ }^{57}$.

\section{Uwagi dla prawodawcy}

Jak widać na wyżej przedstawionych przykładach, reguły sensowności czynności konwencjonalnych i norm kompetencyjnych obecnych w prawie kanonicznym są uwarunkowane teologicznie. Przy tworzeniu lub zmianie instytucji prawnych wola prawodawcy ulega ograniczeniu, pierwszym bowiem źródłem inspiracji dla rozwiązań prawnych jest teologia, która dokonuje intelektualnej refleksji nad Objawieniem, Tradycją, orzeczeniami Magisterium Kościoła ${ }^{58}$.

Prawodawca kościelny musi zawsze przy stanowieniu prawa brać pod uwagę to, że rozstrzygnięcia i oceny teologiczne są niezbędnym i niepodważalnym elementem jego decyzji, zarówno co do faktu istnienia normy, jak

s6 To znaczy, że pytają nupturientów, czy wyrażają zgodę małżeńską i przyjmują odpowiedź (zob. kan. $1108 \$ 2$ oraz art. $7 \$ 2$ k.r.o).

57 Zob. szeroko o tym: P. Kroczek, Does Obligatory Canonical Form of Marriage Contribute to "salus animarum”?, „Folia Canonica”, R. 12, 2009, s. 23-30; P. Kroczek, Should Canonical Form still be Required for the Validity of Marriage? The Future of Can. 1108 CIC 1983, [w:] Estratto da "Iustitia et Iudicium”. Studi di diritto matrimoniale e processuale canonico in onore di Antoni Stankiewicz, red. J. Kowal, J. Llobell, t. 2, Città del Vaticano 2010, s. $857-879$.

58 J. A. Coriden, Canon Law as Ministry: Freedom and Good Order for the Church, New York-Mahwah 2000, s. 139; P. Kroczek, Modelowa wizja pracy kanonisty, „Bielsko-Żywieckie Studia Teologiczne”, 2009, t. 10, s. 219. 
i jej brzmienia. Teologia kształtuje bowiem nie tylko fundament prawa, ale i jego konkretne rozwiązania w nim zawarte ${ }^{59}$.

Pozytywistyczno-legalistyczna postawa prawodawcy nieliczącego się osiągnięciami nauk teologicznych, w oderwaniu lub w sprzeczność z nimi, która może być obecna szczególnie przy tworzeniu reguł sensowności czynności konwencjonalnych, szkodzi funkcjom prawa stanowionego w Kościele ${ }^{60}$, a w rezultacie całej wspólnocie. Prawodawca nie może przy przyznawaniu kompetencji osobom do czynności konwencjonalnych stosować jedynie prawniczych, choć słusznych reguł, takich jak np. reguła 68 ze zbioru Regulae iuris ${ }^{61}$ głosząca, iz: „Potest quis per alium quod potest facere per se ipsum"62. Musi on liczyć się z teologicznymi uwarunkowaniami swoich prawodawczych decyzji. Należy więc stanowczo ponowić postulat, aby prawodawca kościelny troszczył się o poprawność teologiczną i prawną ustaw przez siebie stanowionych.

59 Por. B. Gangoiti, Teologia e fllosofia del diritto del Nuovo Codice, „Angelicum”, R. 60, 1983, s. 517-518.

60 Zob. L. Örsy, Interpretation in View of Action: a Quest for Clarity and Simplicity, „The Jurist", R. 52, 1992, s. 596.

6I Bonifatio PP. VIII, De regule iuris, 3 III 1298, [w:] Iuris Canonici, t. 2, Lipsiae 1881, kol. 1122-1124.

${ }^{62}$ "Jeżeli ktoś może zrobić coś sam, to może to zrobić także przez innego". 


\section{Theological Basis of the Rules of Sense of the Conventional Acts and Norms of Competency in Canon Law and Their Consequences for Legislative Decisions}

Summary

The paper presents the meeting of theology and jurisprudence in the work of church legislator. The conventional acts and norms of competency presented in canon law, such as reception of orders, celebration of marriage, imparting blessings, giving dispensation, giving absolution, pardoning an adulterous partner, giving judgment, being a qualified witness for marriage are reasonable because of the rules of sense giving them a sense. In canon law, the rules in question do not depend on the will of legislator only but they are built on the theological reasoning. The conclusion is that the church legislator, in drafting law, must take into consideration the theological factors. This limits his freedom in making legislative decisions. For instance, he cannot admit in the rules of sense a competence for the conventional acts to those who are not able to carry out the act according to theological rules. The article ends with postulate to the church legislator to take care of theological correctness of law drafted by him.

Keywords: legislation, CIC 1983, rule of sense, norm of competency, conventional act, jurisprudence 
